\title{
COMMUNICATIVE LANGUAGE TEACHING COMPARED TO THE TRAINING OF STUDENTS' PROFESSIONAL DIRECTION
}

\author{
Svetlana Gridneva
}

Yugra State University, Russia

\begin{abstract}
The research deals with the notion of psychological training of students' professional direction, with the analysis of training peculiarities. The alternative of communicative English teaching at higher educational institutions to the training of professional direction is substantiated. The level of professionalism has descended for the last decades in Russia. And the basis of professionalism is a high level of professional direction. We consider professional direction as a structural part of personality direction and the system of components, which directs personality behavior and activity to obtaining professional skills, their development and mastering. The most famous and effective way of development of personality's professional direction is a psychological training. The principles of the training are voluntary participation, "here and now", partner communication, proactive attitude, feedback, confidentiality, and principles of humanistic psychology, i.e. unbiased attitude, acceptance of other people, psychological safety and support. But the psychological training is not available in the educational process of the university. The research in which all the mentioned pedagogical and psychological conditions had been created was conducted at Yugra State University in the framework of communicative English language teaching. During the research the set of theoretical and empirical methods were used. Among them are system analysis and synthesis, modeling, questionnaire surveys, testing, lesson observation, pedagogical experiment, methods of mathematical statistics. The data obtained as a result of our research proved the effectiveness of communicative language teaching for developing students' professional direction that points out the possibility of its use instead of the psychological training.
\end{abstract}

Keywords: professional direction, psychological training, communicative language teaching

\section{Introduction}

The level of professionalism has descended for the last decades in Russia. The proof of it is frequent doctors' mistakes, conflicts between teachers and pupils, politicians' inadequate behavior, man-made disasters etc. All these situations were caused by lack of professionalism. The point is that educational formation of professional begins not after his graduation from the University and not from the first day at work, but from the first day of studying his future profession. And the basis of professionalism is a high level of professional direction.

We consider professional direction as a structural part of personality direction and the system of components, which directs personality behavior and activity to obtaining professional skills, their development and mastering. The components of professional direction are versatile and changeable elements, yielding to correction. We distinguish the following components of students' professional direction: motive of professional choice; interest to the future profession; educational and professional goal-setting; professional expectations; the level of self-reliance in professionally directed educational activities; professionally directed perception of the learning process.

We are of the view that due consideration of the problem of formation and development of students' professional direction is not paid in the teaching and learning process at higher education institutions. In 
academic process at universities much attention is usually paid to the thematic training of bachelors and masters, to the developing of definite competency. Process of development of personality's professional direction is usually formed spontaneously and often depends on the student himself. We consider that it is essential to create psychological and pedagogical environment which will encourage the formation process of the high level of students' professional directionin the academic process of a higher education institution.

The most famous and effective way of development of personality's professional direction is a psychological training. Trainings of professional direction are widely used for students of Psychology (Kunts, 2005). Professional education of future psychologists is based on the variety of trainings, which is determined by the particular nature of their future profession. Consequently, those trainings may be provided by the curriculum or at least be a part of some professional disciplines. As for the students of other professional areas training incorporation into their educational process seems problematic. It means that it is necessary to find an alternative, effectively developing students' professional direction in any professional area. To do it we should consider main features of the training, which help in students' professional direction development.

Phenomenon of training is considered as the most efficient psychotherapeutic humanistic technology in psychology. Practical psychologist's dictionary defines training as a set of methods of development of communicative features and reflexive abilities, of the skill to analyze your own behavior and behavior of the group members, to analyze social situations and your role in them, of the skill to perceive yourself and other people around adequately (Golovin, 2003).

The pedagogical dictionary defines training as a form of interactive teaching, the aim of which is development of competent interpersonal and professional behavior in communication (Kodzhaspirovaet al. 2001).

According to E.V. Andrienko, students carry out consistent process of learning during the training, acquiring social and professional experience, taking into account advantages and disadvantages of subjective, personal qualities, becoming clear in the activity, social and professional sphere being considered as well (Andrienko, 2001).

The training, proposed by L.I.Kunts (Kunts, 2005) as instrument of professional direction development, is a system of specially organized developmental interactions between its participants, each interaction being characterized by unity of such components as: professionally directed contents; developmental situations; interaction process; methods of organizing and realization of this interaction; readiness for interaction; intrapersonal conditions of its effective realization and results of interaction as intrapersonal transformation of its content.

The main strategy of training program aims at creation of abilities for development of independence, initiative, responsibility for one's own life, ability of solving problems, readiness for the further personal and professional development.

The training, established by L.I.Kunts, forms the attitude to the professional activities and to the psychological and pedagogical process as to instrument of professional direction extension, of self-development. It creates a fertile ground for developing of professional future defined by the complex including image of profession and self-image.

The tasks of L.I.Kunts' training were realized with the help of two goal-oriented units. The first unit was created for identification of professional direction type and image of the acquiring profession. The second unit included personal image design of professional future, understanding of the future professional role, students' realizing of their professional resources due to specification and content-related analysis of professional direction (of learning and future professional activity motives, of awareness of activity kinds and of emotional attitude to the acquiring profession). 
The training tasks were being solved through reflection (what am I doing? why am I doing it?) and analyzing of professional activity model. Problem-based personal dialogue was used (Stepanov, 2000). Students were given "open" tasks, having more than one solution. Proposing of new ideas breaking the patterns and common viewpoints were stimulated; students' abilities for self-cognition and self-understanding were developed; respect for individual characteristics of any person and ability to correlate personal acquiring experience with another person's was educated.

The training principles were voluntary participation, "here and now", partner communication, proactive attitude, feedback, confidentiality, and principles of humanistic psychology, i.e. unbiased attitude, acceptance of other people, psychological safety and support (Boljshakov, 1996, Vachkov, 2003, Schneider, 2004, Petrovskaya, 2007).

Training application during psychologists' professional education, as L.I.Kunts considers, foregrounds understanding of possible correction of some characteristics necessary for the future professional activity and leads to the self-understanding as a subject of activity, to the setting the definite goals and finding the ways to reach them. In the course of such work the process of learning becomes personally valued and approach of professional identity becomes justified and mature. The training allows improving the level of motivation for professional future development and stimulation of interest for various kinds of professional activity takes place.

The structure of training program allows students to explore the elements of various kinds of psychologist's professional activity that is reflected in professional behavior and communication, in emotional attitude to oneself as a subject of the future professional activity and to the other people of this profession.

If to summarize all the features of the training mentioned above we can define that the training is humanistic technique which has the form of developmental interaction between its participants in the course of which development of students' communicative characteristics and reflection abilities takes place as well as social situations analysis, acquiring of social and professional experience, development of attitude to the professional activity and psychological and pedagogical process of higher school.

Our task in the framework of teaching foreign language is to create conditions for formation and development of students' professional direction as obtained during the training. The role of such course as "Foreign Language" in the development of personal professional direction is also important as it is the subject of the first two years of studying. The third year of studying according to some researchers (Lubimova, 2000, Buyakas, 2001, Zeyer, 2008 ) is the crucial moment of professional formation and connected either with assurance in professional choice and its further specification or with negative attitude to the future professional activity. Consequently, the earlier student will realize the sense and the purpose of his professional activity and his own place within it the higher level of his professional direction will be and the more first-rate professionals will come into all spheres of society.

In the process of teaching foreign languages at higher school a teacher can choose methods of education according to the purposes and goals. It is possible to name about ten methods of teaching foreign languages which are used today. They are audio-lingual, communicative language teaching, community language learning, direct method, grammar-translation method, natural approach, oral approach, silent way, situational language teaching, suggestopaedia, total physical response. Having analyzed the nature of each method we arrive at a conclusion that the best opportunity to create all necessary conditions for development of students professional direction belong to communicative language teaching.

One of the main principles of communicative language teaching is realization of humanistic approach in education (Miljrud, 2000). Only this approach allows creating positive conditions for active and free development of personality in activity. Necessary conditions can be described in the following way: students get an opportunity of free expression of their thoughts and feelings in the course of communication (non-criticality); 
every participant of group communication is in the center of attention (partner communication); personal selfexpression during professionally oriented learning activity becomes more important than demonstration of the language (non-judgment); contradictory, counterintuitive, even "wrong" opinions, but showing independence and pro-active attitude of students are encouraged (acceptance of others); the use of language material comply with the task of personal speech intention; the learning norm is some bending of the rules and occasional errors.

Humanistic approach implies student-oriented teaching. It means that interacting students become the center of cognitive activity at the lesson. The training is also a humanistic technique the basis of which is interaction of its participants.

The principle of humanistic approach in the course of communicative language teaching in higher education institution allows providing conditions for creative and emotional self-expression, encourages students for communication including professional one. Humanistic approach in the training process creates person-centered emotional interaction between a teacher and students.

The aim of communicative language teaching is developing students' communicative competence, i.e. creative use of means and ways of foreign communication both in written and oral, in receptive and productive form. In the course of communicative competence formation of personal communicative qualities takes place as in the course of professional direction training.

The second principle of communicative language teaching is realization of learning process with activity approach. This principle is based on the theory of goal-directed activity and the theory of speech activity (Rubinstein, 2003, Leontyev, 2004, Leontyev, 2005).

Activity approach in foreign language teaching include creation of problem, nonstandard, professionally directed situations in the learning process; organizing of creative types of educational and professional activity for students; providing variety of professionally directed activity; creation of successful situations in the course of activity; purposeful organizing of transition from outer goal-setting to the inner one; organizing of independent professionally directed activity.

Activity nature of communicative language teaching is realized through activities i.e. tasks worked out by the teacher and containing communicative goal and problem solving for the students. Activities in communicative language teaching are based on game, imitative and free communication. R.P.Milrud and I.R.Maksimova (Miljrud, 2000) distinguish the following types of activities: communicative games; communicative imitations (role plays and problem solving); free communication (socialization).

Activity nature of communicative language teaching is realized through technique "here and now". This formula was proposed by F.Perls in gestalt-therapy the main principle of which is absolute self-acceptance, acceptance of other people and the world as they are, attitude to and evaluation of instantaneous status as a perfect one, not necessary to change or improve (Golovin, 2003). This principle is also one of the foundational principles in the training of professional direction.

Communicative language teaching is put into practice through interactive activities. Interactive activities are impossible to be performed without a partner. They are realized in pair or group work. Only some elements of interactive activity can be performed individually. The task may be gradually done in larger groups and then may become a task for the whole group. It is called pyramid grouping. This is the way of interaction between students which is put into practice as in the course of professional direction training.

Communicative language teaching is applied with the help of organized role communication technique. Role communication is realized through role play, the kind of educational communication which is organized according to the plot, the distributed roles and their relations. Creative role communication needs developed 
social skills. That is why role plays in communicative language teaching include elements of social training (communicative exercises).

The third principle of communicative language teaching is that of socialization. Communicative language teaching organizes an authentic process of students' socialization. In this context the term "authentic" means not only the usage of the original learning material but also creation of methodically reasonable conditions of natural learning communication. The term "socialization" means formation of personal social role in the course of acquiring social interaction experience and learning social values (Miljrud, 2000).

In the course of socialization a person tries and plays various social roles. Person can express oneself through these roles. Judging from the dynamics of playing the role it is possible to get information about earlier social experience of a person.

Socialization in the field of education has a great importance for development of personal identity which is connected with personal intention to take an active part in social events, to make important life decisions, to choose sphere of professional activity. According to B.M.Bim-Bad socialization in educational sphere means integration of personal experience with the social one having been reflected and codified in art images and science notions. Education in the context of socialization is a constantly expanding sphere of personal life activity including rich cultural interaction with outer world and being a part of social and cultural experience selected according to the educational goals.

The main point of socialization is that it develops a person as a member of society which he or she belongs to (Amitrova, 2011). Requirements of the state educational standard of higher professional education aim at such an organizing of learning process which would be able to create conditions for transfer of cultural experience from one generation to another and to allow for students' socialization (Zimnyaya, 1999). Thus we can say about professional socialization in the course of communicative language teaching in higher education institution.

Students' professional socialization is an active, motivated, social process of personal professional formation and development, in the course of which students' primary integration into professional sociocultural sphere takes place. The meaning of professional socialization is in the developing of future specialist as a subject of professional activity owing to the purposeful influence on the formation of students' independence and creativity (Murzagalina, 2010).

If to compare all the principles of professional direction development which are realized through training and communicative teaching we can see the same abilities of creating necessary environment.

Table 1.Comparing the principles of Professional Direction Development

\begin{tabular}{ll}
\hline Principles of Professional Direction & Professional Direction Training \\
Development & $\begin{array}{l}\text { Communicative Language } \\
\text { Teaching }\end{array}$
\end{tabular}

\begin{tabular}{lll}
\hline "here and now" & + & + \\
\hline partner communication & + & + \\
\hline proactive attitude & + & + \\
\hline feedback & + & + \\
\hline confidentiality & + & + \\
\hline unbiased attitude & + & + \\
\hline acceptance of other people & + & + \\
\hline psychological safety and support & + & \\
\hline
\end{tabular}


According to this analysis, applying of communicative language teaching can create necessary psychological and pedagogical conditions for development of students' professional direction similar to the professional direction training as humanistic approach provides necessary psychological comfort for students, activity approach provides students' interaction in the course of communicative competence development and organizes active forms of learning activity, and the principle of socialization realizes development of self-reflection, analysis of social situations and professional expectations, acquiring of social and professional experience by the students.

The research in which all the mentioned pedagogical and psychological conditions had been created was conducted at Yugra State University in the framework of communicative English language teaching. During the research the set of theoretical and empirical methods were used. Among them are system analysis and synthesis, modeling, questionnaire surveys, testing, lesson observation, pedagogical experiment, methods of mathematical statistics. The results obtained are shown in the diagrams below. They demonstrate the level of each component of professional direction before and after the experiment with applying communicative language teaching. The experimental group of students is colored with red and the control group - with blue.
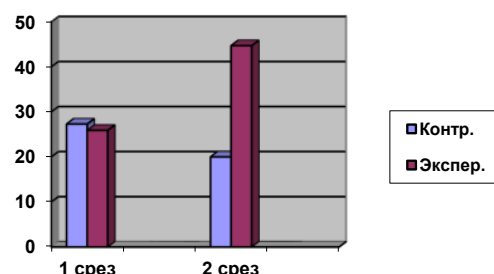

motive of professional choice
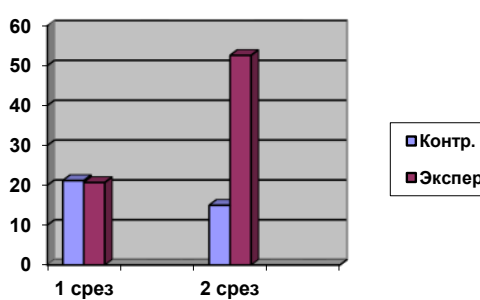

Фэкспер. 1 cpes educational and professional goalsetting
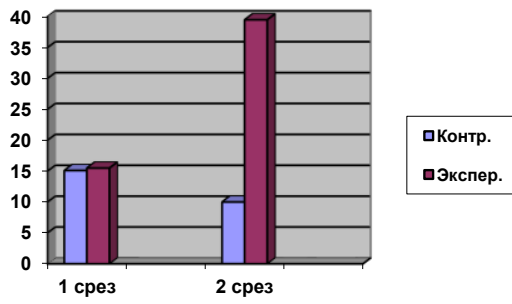

the level of self-reliance in professionally directed educational activities

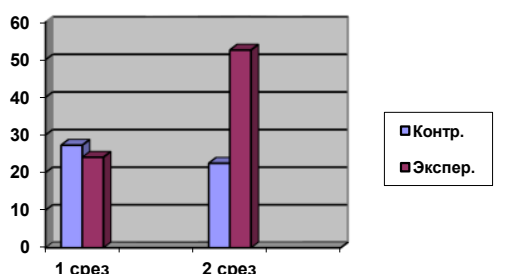

interest to the future profession

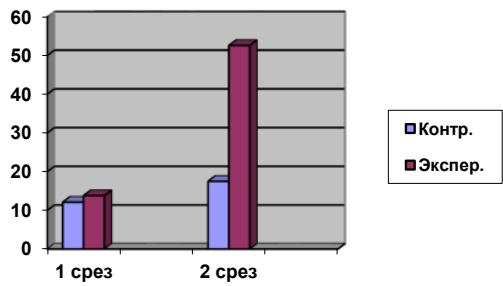

professional expectations

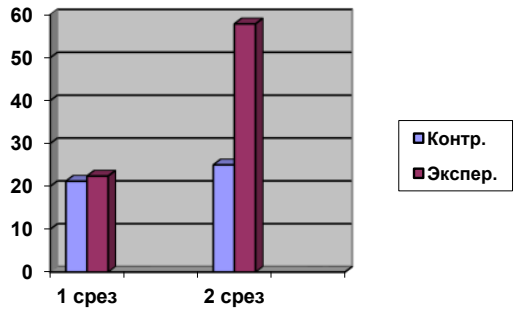

professionally directed perception of the

learning process

Figure 1.The change of professional direction components

The data obtained as a result of our research proved the effectiveness of communicative language teaching for developing students' professional direction that points out the possibility of its use instead of the psychological training. 


\section{References}

Amitrova, M.V., 2011, Vliyanieprofessionalizaciinaformirovanielichnostnihkhkachestvbuduthikhinzhenerovtekhnologov v processeizucheniyainostrannogoyazihka v vuze // Vihssheeobrazovaniesegodnya. № 1.- pp.77 79 .

Andrienko, E.V., 2001,Professionaljnoepedagogicheskoeobrazovanie I razvitielichnostiuchitelya: Ucheb. posobie / E.V.Andrienko. - Novosibirsk: Izd-voNGPU.

Boljshakov, V.Yu., 1996,Psikhotrening. Sociodinamika.Uprazhneniya.Igrih / V.Yu.Boljshakov. - SPb.: Socialjno-psikhologicheskiyjcentr.

Buyakas, T.M., 2001, Process obucheniyakak dialog mezhduprofessionaljnihmilichnostnihmstanovleniem / T.M. Buyakas // Vestnik MGU. Ser 14.Psikhologiya, № 2. - pp. 69-77.

GolovinS.Yu., 2003, Slovarjprakticheskogopsikhologa. - Minsk: Kharvest.

Kodzhaspirova, G.M., Kodzhaspirov, A.Yu., 2001, Pedagogicheskiyjslovarj: Dlyastudentovvihsshikh I srednikhpedagogicheskikhuchebnihkhzavedeniyj / G.M.Kodzhaspirova, A.Yu.Kodzhaspirov. - M.: Izdateljskiyjcentr «Akademiya».

Kunts, L. I., 2005,Professionaljnayanapravlennostjkak factor formirovaniyaobrazabudutheyjprofessionaljnoyjdeyateljnostilichnosti: Na material studentov-psikhologov: Dis. ... kand. psikhol. nauk: 19.00.01 / L. I. Kunts. - Novosibirsk.

Leont`ev, A.A., 2005, Yazy`k, rech`, rechevayadeyatel`nost` / A.A.Leont`ev. - M.: URSS.

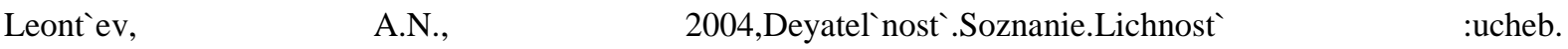
posobiedlyastudentovvuzovponapravleniyuispecz. "Psixologiya", "Klin. psixologiya" / A.N.Leont`ev. - M.: Smy`sl: Academia.

Lyubimova, G.Yu., 2000,Otpervokursnika do vihpusknika: Problemihprofessionaljnogoilichnostnogosamoopredeleniyastudentov - psikhologov / GYu.Lyubimova // Vestnik MGU. Ser 14.Psikhologiya. - 2000. - № 1.- pp. 57-66.

Miljud, $\quad$ R. $\quad$ P., 2000 , Sovremennihekonceptualjniheprincipihkommunikativnogoobucheniyainostrannihmyazihkam / R. P. Miljrud, I. R. Maksimova // Inostranniheyazihki v shkole. - 2000. - №4. - s. 9-16; №5. - pp. 17-22.

Murzagalina, L.V., 2010, Processualjnayamodeljprofessionaljnoyjsocializaciibuduthegovracha / L.V.Murzagalina // Vihssheeobrazovaniesegodnya. - 2010. - № 5 . - pp. 94 - 96.

Petrovskaya, L. A., 2007,Obthenie - kompetentnostj - trening: izbrannihetrudih / L.A.Petrovskaya. - M.: Smihsl.

Rubinshtejn, S.L., 2003, By`tieisoznanie. Chelovekimir / S.L.Rubinshtejn. - SPb.: Piter.

Stepanov, S.Yu., 2000, Refleksnayapraktikatvorcheskogorazvitiyacheloveka I organizaciyj / S.Yu.Stepanov. M.: Nauka.

Schneider L.B., 2004, Treningprofessionaljnoyjidentichnosti: Rukovodstvodlyaprepodavateleyjvuzovipraktikuyuthikhpsikhologov / Avtor-sost. L.B. Schneider. - M.: IzdvoMoskovskogopsikhologo-socialjnogoinstituta; Voronezh: Izd-vo NPO «MODEhK».

Vachkov, I.V., 2003, Osnovihtekhnologiigruppovogotreninga: Psikhotekhniki: Ucheb. posobie / I.V.Vachkov. M.: Osj-89.

Zeer, Eh.F., 2008,Psikhologiyaprofessionaljnogosamoopredeleniya v ranneyjyunosti: uchebnoeposobie: uchebnoeposobiedlyastudentov, obuchayuthikhsyapospecialjnosti 030500 "Professionaljnoeobuchenie" (pootraslyam) / Eh. F. Zeer, O. A. Rudeyj. - M.: Izd-voMoskovskogopsikhologo-socialjnogo in-ta; Voronezh: Izd-vo NPO "MODEhK".

Zimnyaya, I. A., Bodenko, B.N., Krivchenko, T.A., Morozova, N.A., 1999,Obthayakuljturacheloveka v sistemetrebovaniyjgosudarstvennogoobrazovateljnogostandarta / I.A.Zimnyaya, B.N.Bodenko, T.A.Krivchenko, N.A.Morozova. - M.: Issled. centr problem kachestvapodgotovki specialistov. 